\title{
Designing Reading Materials for ESP Students Vocational High School of Medical Science
}

\author{
Imam Fauzi1,a, Dian Hanifah2,b \\ ${ }^{1}$ Faculty of Economic and Business, Accounting Major, Serang Raya University, Indonesia \\ ${ }^{2}$ SMK Kesehatan Husada Pratama Serang-Banten \\ a imam_unyur@yahoo.com; b dianhanifah21@gmail.com \\ ${ }^{*}$ Corresponding Author \\ Whatsapp Number [081238072643 / 081911088677$]$
}

How to Cite: Fauzi, I. \& Hanifah, D. (2019). Designing Reading Materials for ESP Students Vocational High School of Medical. International Journal for Educational and Vocational Studies, 1(4), 314-321

\section{ARTICLE HISTORY}

Received: 13 May 2019

Revised: 20 June2019

Accepted: 6 August 2019

KEYWORDS

Reading materials;

ESP;

Reading skills;

\section{ABSTRACT}

The study attempted to design reading materials for Medical Science students at one of Vocational High Schools in Serang. To produce satisfactory teaching materials, the researchers conducted the following steps: doing needs analysis, reviewing the principles of materials design and reading in a foreign language, designing course framework, syllabus, the reading materials, and implementing the sample lessons. Researchers employed qualitative methods in gathering the data. The instruments used were questionnaire and interview. The questionnaire was addressed to students, alumni, teachers and institution. The interview was collected from the users. The needs analysis was carried out by distributing questionnaires. The result of needs analysis, became the basis for the researchers to design course framework. The course framework was then developed into a syllabus. Finally the syllabus became the basis for designing reading materials. Reading materials for Vocational High School applied a topical syllabus. Each lesson or unit discusses different topics, greeting and introduction. Introduction about nurse, health, dialogue between nurse and patient, eat healthy food, profile a nurse, tools, disease, nutrition, the healthy diet pyramid. Each lesson also adopted various reading skills or strategies. They were skimming, scanning, and guessing meaning from context. When the materials had been designed, the researchers implemented six out of ten lessons of the coursebook. The results were satisfactory. Most students mentioned that the coursebook was related to their field of study. The majority of the students said that the materials were understandable and interesting. They also said that they were satisfied with the reading materials.

This is an open access article under the CC-BY-SA license.

\section{INTRODUCTION}

In school, language become one important component to be learned, so does in vocational high school. In this school students learn English to improve their competency in wider social life, and the students expected to be able to make communication in English as an international language. A vocational school is a kind of educational institution, which, depends on country, may refer to secondary or post-secondary education designed to provide vocational education, or technical skills required to perform the tasks of a particular and specific job. In the case of secondary education, these schools differ from academic high schools which usually prepare students who aim to pursue tertiary education, rather than enter directly into the workforce.
Nowadays, the government finally decided to try out the new designed Curriculum, the 2013 Curriculum. It is an operational Curriculum which is formed and practiced by each school Indonesia. 2013 Curriculum will make a lot of changes to the face of education system of this country. Although the 2013 Curriculum offers significant breakthroughs in improving the quality of teaching and learning process, the success of this Curriculum depends on how schools implement it. In teaching and learning process, teacher should consider the learning materials which are used in the class. Textbook is one of the learning materials which are commonly used. It is kind of printed materials which have an important part in teaching and learning process. According to Tomlinson (1999:2), textbook is a main learning material which is usually used by teacher and students. Textbook also has many 
advantages in teaching and learning process.

There are four skills in English, namely listening, speaking, reading, and writing. For many students, reading is the important of the four skills in second language. Reading is one of the skills in English that has to be mastered by the students when they are learning English. Because of that, students have to learn reading as well as the other skills if they want to master English. According to Nunan (2003:68) reading is a fluent process where in building the meaning, readers should combine information from the text with their own background of knowledge. Referring to the reading skill, the researchers find some problems such as students still lack of vocabulary that make them cannot follow English learning effectively, and they need specific materials that fits to their study background, and teachers also should create and give the specific materials so that students could understand all materials for their future job. There are some factors that implicate students to comprehend hardly the English text which are formulated into four problems. First problem is from Vocational high school of medical science Serang has not fulfilled the needs of reading English textbook for its students.

Secondly it comes from the teacher. Teacher does not give much attention with the students need in reading. Teacher just gives materials and asks students to answer the questions without giving some guidances how to comprehend the text. Teacher also does not try to build interaction with the students. It makes the students feel bored and do not enjoy the lesson. The third problem is derived from the students. The students' vocabulary is still low. As a consequence, they get difficulty in interpreting the meanings of the difficult words. They are not able to find the detail information of a text. Besides that, students do not have motivation in reading as it is reflected by their behavior in the class. Then when teacher asks them to read a text, they just look at the text or chat with their friends during learning in the classroom. They are very noisy in the classroom and do not pay attention toward the teacher's explanation. And those can be obstacles for their comprehension in reading.

The last problem is the material provided by the teachers. Learning material is the core of the knowledge which is transferred to students. Actually, most of the material being taught were boring and monotonous. Therefore, the students were not attracted to get involved with the existing material that make them have not good reading mastery. Based on the problem identification above, the researchers attempt to design reading materials for ESP students at vocational high school of medical science. The researchers expect that reading material for ESP students will help the students understand English and give them much information from reading materials. After the researchers investigated some current issues about the reading materials for ESP students, the research questions are arisen;
1. What are the needs of vocational school students regarding reading skill?

2. What are the needs of school regarding reading skill?

3. How do students respond to the reading materials which have been designed?

Referring the above-mentioned research questions, the objectives of the research are then formulated as follows:

1.To find out what the needs of vocational school students are regarding reading skill

2.To find out what the needs of school are regarding reading skill

3.To find out how students respond to the reading materials which have been designed

There have been some scientific researches on developing English materials (Ilyas, 2014; Jayanti, 2015; Ketut, 2015). The first research was conducted by Ilyas (2014). The research focused on designing reading materials for telecommunications engineering students, the researcher stated that all respondents said that lesson 1 was related to telecommunications engineering. $83 \%$ of the students said that the lesson was understandable. $67 \%$ said that the lesson was interesting, and $67 \%$ mentioned that they were satisfied with the lesson. Jayanti (2015) stated that the students need English to understand instructions in computer terms $(39,7 \%)$ and it is necessary for them to communicate in written and oral form actively (34,5\%). $22,4 \%$ of the respondents also state that they need English to read reference related to the development of technology as what their major demands. In relation to reading materials as the product of this research, 78,6\% respondents thought that the use of texts related to computer engineering and networking in teaching and learning Reading skills is very important. The need of skills in English that they want to master are speaking $(35,5 \%)$ and reading $(25,5 \%)$.

Ketut (2010) revealed that the developed material could improve the students' reading comprehension. It can be seen from the result of pre-test, post-test I, and post-test II that measured the students' reading comprehension. The students' mean score for those tests, which reflect the students' reading comprehension, increased from 40.9 in pre-test, to 66.3 in post-test I and 79.1 in post-test II. Based on the result of the questionnaire, the students had strongly positive attitude toward the developed material, and from the observation in developing and implementing the developed material, the problems that were found can be classified into technical and financial problems. To develop the students reading ability, they should have had a textbook that can cater the needs of the learners to reach an optimum result in learning English as a second language. One way of fulfilling the needs is through designing teaching materials by the teacher.

After having insightful results of the research studies comprehensively discussed above, the researchers attempt to design the reading materials for the second-grade students at Vocational High School Medical Science. 
Because designing reading materials is one of the effective manners to make the successful teaching activities. Besides there are some advantages the EFL teachers and learners can get in using the designed reading materials such as it can assist the teachers practice in teaching reading in a foreign language, lead effectively the students in the more active teaching and learning process, achieve the classroom learning purposes as defined as in the designed syllabus, and meet the students need in the EFL studies and make the students understood, and enjoy during the lesson.

\section{Reading in EFL}

Reading activities can be divided into 3 stages: pre-, while-, and post-reading. Pre-reading, according to Zhang (1993) says that pre-reading activity enables learners to get the comprehension in Reading since it provides schemata explicitly. Pre-reading can activate the relevant schema or background knowledge the learners have already known before. Unfortunately, teachers tend to neglect the prereading procedure claiming that there is not enough time. In fact, pre-reading activities motivate students before the actual reading takes place. For example, teachers can ask students questions that arouse their interest while previewing the text.

While-reading stage (or interactive process) has an aim to develop students' ability in undertaking texts by developing their linguistic and schematic knowledge. Paran (1996:2) in Alyousef (2006) believes that teachers can design a balanced approach to teaching reading by integrating both top-down and bottom-up processes and providing the students flexibility in choosing the reading tasks. Haller (as cited in Alyousef, 2006) modeled a number of school-based post reading activities which enhance learning comprehension through the use of matching exercises, and comprehension questions. Basturkmen (2006:17) also supports the idea in which ESP is about preparing learners to use English within academic, professional, or workplace environment.

To designing ESP material, Steven (in Dudley-Evans and St John, 2002) proposed two absolute characteristics: four absolute characteristics and two variable characteristics. These two characteristics can be the focus of attention to anybody who would like to design and develop ESP materials. Four absolute characteristics of ESP are it is designed to meet specified needs of the learner, is related in content (that is themes and topics) to particular disciplines, occupations, and activities, is centered on language appropriate to those activities in syntax, lexis, discourse, semantics, and so on, and is in contrast with 'General English'. To summarize, ESP is concerned with English for special purpose. The syllabus of ESP is designed to meet the specific needs of the learners.

\section{METHODS}

Subject of the research was 32 students at the second- grade students of Vocational high school medical science which consists of 28 female students and 4 male students. The research activities stemmed from administering questionnaires for students, alumni and institution or teacher. Analyzing the data from those questionnaires, designing course framework, designing syllabus, designing reading materials, and the last implementing sample lessons. There are 32 questionnaires for students before and after implementation materials, seven questionnaires for alumni, three questionnaires for teachers and then one questionnaire for institution of Vocational School.

\section{Research Design}

The goal of this research was designing reading materials for vocational high school student medical science at Husada Pratama Serang. The final product of the research was reading materials or coursebook in the form of a conventional material by applying qualitative research.

Based on five qualitative traditions of inquiry (a biography, a phenomenological study, a grounded theory study, an ethnography, and a case study), this research adopted a case study. Since this was a case study, the research was bounded by time and place and used interviews and questionnaire as sources of information. Cresswell (1998) states that "a case study is an exploration of a 'bounded system' or a case or multiple cases over time through detailed, in-depth data collection involving multiple sources of information rich in context. This bounded system us bounded by time and place, and it is case of being studied - a program, an event, an activity, or individual".

\section{Doing Needs Analysis}

By doing the needs analysis, the researchers intended to find out what the students need in EFL learning materials and discover what kind of suitable subjects that the students learned from the institution in order to produce adequate reading materials. Richards (2001) states that "needs analysis in language teaching may be used for a number of purposes such as to collect information about a particular information and about a particular problem learners are experiencing, and to identify a gap between what students are able to do and what they need to be able to do."

Besides doing needs analysis, the researchers also administered questionnaires to alumni, school and teacher. Finding out what alumni, school and teachers highly expect from English lessons in order to be able to prepare and design the teaching materials that fit to their expectation.

The needs analysis is conducted to identify what problems students face to understand and interpret the English text, how important English for students, how difficult the English language especially in reading text, and what strategies (skimming, scanning and guessing meaning from context). In doing need analysis for alumni, the researchers expect to find out how often the students found difficulties in reading, writing, speaking, 
and listening in English, what difficulties in reading English texts, speaking English, writing in English, and listening to English. By conducting need analysis, the researchers also highly expect to find out what the purposes of giving lessons, especially reading to students, and how important the English language for students.

\section{Designing Course Framework}

Based on the need analysis, the researchers then identify the specific aims of the course, namely about health, introducing a medicine and etc. Therefore, the researchers designing course framework. This course framework contains specific points of reading themes and topics. Information of classroom activities, the length of study session, the number of the course meetings, and the number of participants. The course framework became the basis to write the syllabus.

\section{Designing Syllabus}

Based on course framework, the researchers design a reading syllabus. The syllabus outline coursebook in detail concerning reading text and classroom activities and strategies. The syllabus also acted as guidance for producing reading materials.

\section{Designing Materials for Reading}

Based on the syllabus, the researchers design materials that can be used by the students of Vocational High School Medical Science Husada Pratama Serang. The materials consisted of five lessons each lesson covered two parts. Reading skills involved skimming, scanning, and guessing word meaning from context. Building vocabulary took in exercises of matching, filling in the blank and answer question of the text. Expansion encompassed discussion, reading aloud, and giving exercise for students. Since the topical syllabus approach is adopted by the researchers, each lesson covers different topics in the field of Vocational High School Medical Science. Based on the need analysis, the researchers put texts taken from internet, textbook by adapting and adopting. The researchers prefer adapting and adopting the texts since the researcher want to keep the authenticity of the texts. the researchers only adapted the texts when they are suited to the reading activities.

\section{Implementation}

After designing the lessons, the researchers carry out the implementation by piloting the sample unit (questionnaires of students about the materials). The purpose of doing the implementation is to find out the responses of the students toward the materials having been designed. The researchers only implemented 10 lessons.

The researchers distribute the questionnaires after implementing certain lesson. The points of questionnaires are whether the material is suitable to students or not, whether the materials is understandable or not, whether the material is interesting for the students or not, in general, the material is satisfactory or not, and comments for materials improvement (if there is any).

This study used data collection techniques as follow:

\section{a.Interview}

The researchers used questionnaire as an interview to collect the data. Interview was to know the need analysis of students before and after implementation process to explore the views, experiences, beliefs and/or motivations of students. Interview for the purposes of need analysis. After implementation process of this study, the purpose of questionnaires is to know students' response to the material created, for students understanding and students' satisfaction. There are four kinds of questionnaires, for students, alumni, institution and teachers of the school. The questionnaires for 32 students are distributed. The questionnaires for alumni are 7 people. For institution only one questionnaire, and there are 3 questionnaires for teachers of the school.

\section{b.Questionnaire}

Data collection was gathered by distributing the questionnaires. The questionnaires for the students are given before class. So, all the students give different information before the class. In the questionnaire, all the students answer the question from the researchers. The questionnaire for alumni has been given to 7 people. And the questionnaire for institution of school done with one questionnaire and communicating directly.

The technique of data collection in the implementation stages have done after the lesson. Every student answered the question whether the material was interesting, easy to understand or needs improvement. The researchers asked them to answer honestly. The questionnaires have done in bahasa in order to make the subject of the study understand the questionnaires more easily to answering what they have in their mind.

\section{Data Analysis}

The data analysis started from the data collection from students, alumni and institution or a teacher of the school. In this line about the result of students' satisfaction, and this research stopes until material are completed and implemented and refinement of subsequent and another researcher.

The writer analyzed the data from some questionnaires that have been given for students, alumni, teachers and institution. The questionnaire for students was given before and after implementation of the materials. Questionnaire for teachers was given before the researchers come to the classroom. Questionnaire was carried out for alumni and institution while the researchers were implementing the materials. 


\section{RESULTS AND DISCUSSION}

The research findings are structurally arranged based on the research questions. Those are (a) what are the needs of vocational school students regarding reading skill; (b) what are the needs of school regarding reading skill; and in addition (c) materials implementation. (d) how do students respond to the reading materials which have been designed.

\section{a)The Needs of Vocational School Students Regarding} Reading Skill.

The research shows that the students need firstly to learn English since they still find difficulties in using it. Secondly, they need to learn four skills with the emphasis on reading and speaking. Thirdly, they need reading texts taken from textbooks and internet to broaden their knowledge. Finally, they need to know and understand reading strategies such as skimming, scanning and guessing word meaning from context. The strategies are important to help them read English texts.

The questionnaire explains that whether students have difficulties in using four skills (reading, listening, writing and speaking) in English. The questionnaire also informs that the students think those four language skills are important for their success in study and career. It is indirectly concluded that the students are aware of the importance of English for both their education and their future career.

The difficulty faced by the students becomes the focus of attention by the researchers also put speaking and writing activities. In the reading materials, by the end of each lesson, the researchers put 'expansion'. The expansion consists of speaking and writing activities. For speaking, the activity is reading aloud and for writing the activity is answering some questions of the text.

The information gave the researcher the idea to include such reading text in the reading materials the researchers designs. Besides, all the passages are related to the subjects which students learn. Those passages are adopted and adapted from many sources, and those passages are varied. It is done to expose the students with various kinds of text, and make them accustomed to the text genre. The last point of questionnaire for the students informed that they are not quite accustomed to the reading strategies or skills in understanding reading texts. This could be one of the reasons why they feel texts are difficult. They do not know strategies for reading texts to get the information needed.

In short, what the students need from reading materials the researchers design has been fulfilled. The maerial caters what the students expect to learn, and it also pays attention to the reading strategies proposed by the experts in understanding passages. The researchers acquired the result of interview from students, alumni and teachers. The interview by using questionnaires.

Paying much attention to the result of questionnaire from the students, the questionnaires given before learning or at the first meeting, and it can be concluded that $62.5 \%$ of students sometimes found difficulty in using English for reading. $21.8 \%$ of the students often found difficulty in reading, and only $15.6 \%$ of the students seldom found difficulty in understanding English texts. In terms of writing in English, $62.5 \%$ of the students answered that they got difficulty, while 37.5 $\%$ of the students answered that they got difficulty in writing very often. This is contrary to speaking in English in which $37.5 \%$ of the students said that they sometimes found difficulty, $46.8 \%$ of the students often found difficulty, while $15.6 \%$ of the students answered that they seldom found difficulty in speaking in English. The majority of students answered that listening was difficult. $59.3 \%$ of the students said that they found difficulty in listening very often. $28 \%$ of the students said they sometimes found difficulty in listening. And only $12.5 \%$ the students saying that they seldom found difficulty in listening.

Since the researchers designed reading materials, the researchers focused on reading skills. Based on the data, the majority of students said that they sometimes found difficulty in reading. For the researchers, some students gave information that reading was not really difficult for students, and the researchers could adopt reading texts from many sources as authentic materials.

The second point of questionnaire that asked the students opinion about how important English was for their success in their studies. $53 \%$ of students said that reading was very important, $31 \%$ students said that reading was important and only $12.5 \%$ of the students said that reading not important, While $31 \%$ of the students said writing was very important, $46.8 \%$ of students said that writing was important, and $21.88 \%$ of the students said that writing was important enough. Then $56.2 \%$ of the students said that speaking was very important for their study, 31\% said that speaking was important, only $12.5 \%$ of students said that speaking was important enough for their study. And $28 \%$ of the students said that listening was important, $18 \%$ of students said that was very important, $31 \%$ of students said that listening was important enough, and $21 \%$ said that it was not important for their study. This proves that the students are aware of the importance of English for their study.

The third point of questionnaire that asked the students opinion about how important English was for them when they work later. $50 \%$ of the students said that reading was very important for they work later, $31 \%$ of students said that it was important, and $18 \%$ said that reading was important enough for they work later.

$46.8 \%$ of the students that writing was very important, $37 \%$ of the students said that writing was important enough, and $15 \%$ said that it was not important. In speaking $71.8 \%$ of the students that speaking was very important for their success in career later, $21 \%$ said that it was important, and $6 \%$ said that speaking was important enough. Then $56 \%$ of the students said that listening was important, $34 \%$ of the students said that it was important enough and only $9 \%$ of students that it was not important.

The last point of the questionnaire for the students was how often the students did the reading strategies. The strategies the researcher included were finding skimming, scanning, and guessing word or meaning of text. The answers were varied, but the majority of informants said that they seldom did those strategy of finding main ideas when reading. $68 \%$ of the students said that they often finding main point of text when reading, $15 \%$ of the students said that they very often using this strategy, and similar to that, also $15 \%$ said 
that they were seldom to using this strategy. $53 \%$ of the students said they seldom did skimming. $46 \%$ said that they were often using this strategy. And not much different that $56 \%$ of the students said they seldom did scanning, $31 \%$ of students said that they were often using this strategy, $12 \%$ of students said that they never using that strategy. And $31 \%$ of the students said that they often did guessing word of the text, $46 \%$ of the students said that they seldom using the strategy, $15 \%$ said that they never using, and only $6 \%$ said that they were using this strategy.

b) The Needs of Vocational School Regarding Reading Skill. The research reveals that the school needs the coursebook for their students, especially the specific materials of reading. The school wants the students understand in reading skill. In this research, the questionnaire gives information that the school explains that the work to be obtained by Husada Pratama's graduates are assistant pharmacists and nurse. So, English is important for their life and their future life in work place.

The researchers gave the questionnaire for institution, before the researchers come to the classroom. The first questionnaire was are the English language skills was needed for students. The institution gave information that English most important and it was highly needed for students, not only in their school study process, but also for their future career.

The second questionnaire about what the purpose of giving English subjects, especially reading skills to students. The institution said that the purpose of English subject to students was to make the students easier to communicate with international language and have reading skill, make the students easier to know all kinds of material by reading, such as knowing some tools and so on, and give the basic knowledge for students. The last questionnaire about what kind of work will be obtained by Vocational High School Graduates. Informants said that all the graduates worked as a Nurse Assistant and Pharmacist Assistant.

\section{c) Materials Implementation}

Before the researchers gave the materials for students, the researchers gave some questionnaires for students, alumni, teachers and institution. The questionnaires have been given before learning. After getting the results interview by using questionnaires, the researchers started to create or design the needs for this research. In the first time the researchers have designed course framework, syllabus and materials for students. The activities and materials in the classroom based on course framework and syllabus.

Actually, there are ten lessons in the materials, but the researchers only gave six lesson for students, because the researchers do not have more time to research again in this class, because time is less, at that time there are long holiday and after that students practice field work. Then the researchers just reached in lesson six.

Now the first lesson about greetings and introduction by using scanning strategy, with expansion discussion and practice. The activity that researchers gave them formal-informal greetings and introduction, the researchers asked the students to read, to understand it and also asked them to create a dialogue with their friend using greeting-introduction like the example that have been given, after that students practice the dialogue.

The second lesson about introduction to nurse by using scanning and guessing word meaning strategy, with expansion discussion, guessing the underline word meaning and answer some questions. In here the researchers gave them a text about nurse, what is nurse, where they work and what they work. The researchers asked the students to read the text, after that we discussed and the researchers asked the students to find meaning the underlined words and after that answered some question of the text.

The third lesson about health by using scanning and skimming strategies, with expansion discussion and answer the question. The activity was similar with the second lesson, we discussed together and after that students answered some question of the text.

The fourth lesson was the conversation nurse and patient, by using scanning and guessing strategy. With expansion speaking practice and guessing word meaning. The researchers asked the students to reading a conversation, and then asked them to find out the meaning of underlined words. After that students create a conversation with patients or a doctor, then they practice the conversation in front of the classroom.

The fifth lesson was about eat healthy food by using skimming and scanning strategies, with expansion discussion and answer some question. The activity was students reading a text, discussing together, and after that answering some questions.

The last lesson was about profile a nurse by using scanning strategy. And with expansion discussion and answer some question. In here the researchers gave a text about profile a nurse to students. Then they read the text and understand it. We discussed together after that answered some questions of the text.

The explanation of materials implementation above, the researchers only gave six lessons for students, and hopefully the researchers could continue to give them more specific materials in the next season. And hopefully the researchers could design some coursebook for vocational medical science, not only for nurse, but also for pharmacist. After the materials have been given to students, for the last research, the researchers gave the questionnaire after materials implementation, the researchers found how students respond to the reading materials which have been designed for them in the classroom.

d) How Students Respond to the Reading Materials Which Have Been Designed

The last is the questionnaire for teaching materials. After designing reading materials, the researchers did an implementation or piloting sample units. As previously mentioned, the researchers implemented six lesson out of ten lessons having been made.

The researchers put four items in the questionnaire that had to be answered based on the students' personal opinion. Those items were whether the lesson was related to the subject of Medical Science, whether the lesson was understandable, meaning the instruction in the materials were clear, whether the lesson was interesting for the students, and whether 
the students were satisfied with the lesson.

All respondents (32 students) said that lesson 1 was related to vocational medical science. $93 \%$ of the students said that the lesson was understandable, $87 \%$ said that the lesson was interesting, and $90 \%$ mentioned that they were satisfied with lesson 1 .

For the lesson 2, here all of the students said that lesson 2 was related to the subject they were learning, $96 \%$ of the students said that lesson 2 was understandable, $93 \%$ of the students said that it was interesting, and all of the students said that they were satisfied with the lesson 2.

$93 \%$ of the students said lesson 3 was related to their field of study, and only $6 \%$ said that it was not related. All the students said that the lesson 3 was understandable, $90 \%$ of the students said that it was interesting, and $90 \%$ of the students said that they were satisfied with the lesson 3 .

For lesson 4, all students said that the lesson was related with their study in vocational medical science. Similar with point one, that all students said that the lesson was understandable, $93 \%$ of the students said that the lesson was interesting and $90 \%$ of the students said that they were satisfied with lesson 4 .

With respect to lesson 5 , all the students said that the lesson was related to the subject they were studying. $90 \%$ of the students said that the lesson was understandable, and only $9 \%$ of the students said that they were not understand, $93 \%$ of the students said that they were interesting with the lesson, and all the students said that they were satisfied with the lesson 5 .

The last for lesson 6 similar to previous lesson that all the student (100\%) said that the lesson was related to their study or subject. $96 \%$ of the students said that lesson 6 was understandable, $93 \%$ of the students said that it was interesting, and all the students were satisfied with the lesson 6 .

To conclude, the majority of the students said that the six lessons were related to their field of study, were understandable, interesting, and satisfactory. It proves that the reading materials the researchers designed was successful.

\section{CONCLUSION}

Based on the findings and discussions, the researchers draw some points in conclusions. The points are researcher's self-reflection of what they have done, and hopefully they can give a valuable contribution for the readers of this research.

The first step to do in designing teaching materials is finding out the needs of students or users that will be designed. This is done to find out what they really need, what problems they found when learning English language. And this is done to make the teaching materials more effective and reach the goals of teaching and learning.

The second step in designing teaching materials for vocational medical science students is finding out the needs of stakeholders. The stakeholders can alumni, teachers and institution. The alumni give the information about the real situation when later the students graduate from the school or institution. The teachers can inform what it needs to improve the quality of its graduate, to improve students reading skill, and the institution tell about needs the specific materials for students' skills to be able to know basic knowledge for their future career as a nurse assistant.

The third is designing framework, there are some points to be taken into account. those points cover the global aims of the course, general points of reading themes and topics, information of classroom activities, the length of study session, the number of the course meetings, and the number of participants. the information can surely contribute to the making of syllabus.

Fourth, syllabus design is another step that is crucial enough in designing teaching materials. the syllabus outlines teaching materials in detail concerning reading texts, topics, and classroom activities and strategies. In designing the teaching materials, the syllabus must be the reference and guidance.

And the last step in designing teaching materials is implementation. Implementation is piloting the sample unit. This is to know whether the materials we have designing successful or not. Besides, this is done to see the comments and responses from the students. After all, they are the ones who learned from that teaching materials.

After the teaching material was implemented, students responded that they understand with the materials which researchers have designed, students are strongly interested with the lessons and they were satisfied with the lesson, because the materials are more specific in their study and that was important for their future life or in their workplace.

Based on the findings of research, materials design, and implementation, the researchers suggest some points for other researchers who like to do the research on this topic. The suggestion is expected to bale to give any contribution to the field of material design or material development, especially in designing reading materials in the context of English for specific purposes.

First, in making questionnaire for needs analysis, the questions must be very clear to the respondents and must ask questions that are related to the planned materials. The questions can over the background information of the respondents, the present information of the respondents, what the respondents expect recently, and what the respondents expect in the future. if those points can be covered, at least the needs analysis can give sufficient data for the basis of decision making.

Second, in designing reading materials for Vocational Medical Science, the underlying theories and principles of reading in a foreign language and the principles of designing materials must be highlighted very seriously. The finished materials will be proof whether the materials are really interesting and can satisfy the students or not.

Third, take the implementation very seriously. Through this activity, the designer of the teaching materials can be 
whether the materials are successful or not in catering the needs of the students' reaction, comments, and responses. Sometimes such responses can give more information rather than what the students write on a piece of paper.

Finally, material design is an on going process. There is always revision, starting from needs analysis to implementation. Even, when the materials are used later, still there must be revision in accordance with the development of science and technology. In terms of Vocational Medical Science in which the subject and new invention change very quickly, the materials must also change and be revised. So, the materials can keep up with the development of science and technology.

\section{REFERENCES}

Alyousef, H, S. (2006). Teaching Reading Comprehension To Esl/Efl Learners.144

Ana, K, T, A. (2010). Developing E-Learning Based English Reading Materials For The Tenth Year Multimedia Students of SMK N 3 Singaraja.

Basturkmen, Helen. (2006). Ideas and Options in English for Specific Purposes. London: Lawrence Erlbaum Associates.

Dudley-Evans, T., \& St John, M. J. (2002). Developments in English for Specific Purposes- a Multi-Disciplinary Approach. Cambridge: Cambridge.

Ilyas, H, P. (2010). Designing Reading Materials For Telecomunications Engineering At Telkom Academy Jakarta.

Jayanti, E,D. K(2015). Developing Reading Learning Materials For The Grade X Students Of Computer Engineering And Networking Program At SMKN 1 Pundong In The Academic Year of 2014/2015.

John, W, Cresswell. (1998). Qualitative Inquiry and Research Design: Choosing Among Five Traditions. California: Saga Publication.

Nunan, David. 2003. Practical English Language Teaching, International Edition. New York: The McGraw Hill.68.

Richards, J. C. (2001). Curriculum Development in Language Teaching. Cambridge: Cambridge University Press.

Tomlinson, B. (1998). Materials Development in Language Teaching. Cambridge: Cambridge University Press.

Zhang, Zhicheng. (1993). Literature review on reading strategy research. 